\title{
Milk Bromatological Parameters of Different Goat Breeds of Goat Research Station, Bandipur, Nepal
}

\author{
N. Poudel ${ }^{1, *}$, B. Poudel ${ }^{1}$, N. Bhattarai ${ }^{1}$, R. Kandel ${ }^{2}$, A. Shrestha ${ }^{2}$, S. Malla ${ }^{2}$, B. Regmi ${ }^{3}$ \\ ${ }^{1}$ Agriculture and Forestry University, Chitwan, Nepal. \\ ${ }^{2}$ Goat Research Station,Bandipur, Tanahu, Nepal. \\ ${ }^{3}$ Veterinary Laboratory, Pokhara, Nepal.
}

How to cite this paper: N. Poudel, B. Poudel, N. Bhattarai, R. Kandel, A. Shrestha, S. Malla, B. Regmi. (2020) Milk Bromatological Parameters of Different Goat Breeds of Goat Research Station, Bandipur, Nepal. International Journal of the Science of Food and Agriculture, 4(3), 244-248. DOI: $10.26855 /$ ijfsa.2020.09.003

Received: May 7, 2020

Accepted: June 20, 2020

Published: July 27, 2020

"Corresponding author: N. Poudel, Agriculture and Forestry University, Chitwan, Nepal.

Email: nishapoudel26@gmail.com

\begin{abstract}
A study was conducted in Goat Research Station, Bandipur to investigate the milk quality parameters of different genetic groups of goat. Out of 47 milk samples, 11 samples were collected from pure Boar goat, 11 samples from pure Saanen goat, 23 samples from cross-breed of Khari with Boar and 2 samples from cross-breed of Khari with Saanen. $10 \mathrm{ml}$ of milk sample was collected manually from each she-goat in a sterile plastic bottle early in the morning and analyzed by using ultrasonic milk analyzer (MILKOTESTER) for physiochemical parameters, including fat, protein, SNF, lactose, density, salt and freezing point. All the parameters were statistically analyzed by using general linear model and SPSS 16. P-value less than 0.05 (i.e. $\mathrm{p}<0.05$ ) was considered as statistically significant. Among the evaluated milk parameters, fat, protein, salt and freezing point were found significantly different in comparisons with different breeds of goat. Protein, SNF, lactose, salt and freezing point were higher in pure Boar milk. While fat was found higher in the milk of Boar and Khari cross. Similarly, the density was found to be higher in the pure breed goat milk. These findings are important to consider in order to maintain the quality of different milk products.
\end{abstract}

\section{Keywords}

Goat, GRS, Milk, Bromatological Paramete

\section{Introduction}

Goat husbandry has been a part of agriculture since almost the first use of domestic animals and presently its popularity is increasing throughout the world, this increase is reflected to a greater degree by the rise in the number of small herds maintained by individuals either as a source of income or as an avocation [1]. Goat milk and its products have provided humanity with vital lines of nutrition, economic survival and well-being around the world though goats produce only about $2 \%$ of the world's total milk supply [2]. The demand for milk and milk products is on the rise in the tropical developing countries due to rapidly increasing human population which can be met by increasing ruminant livestock population [3]. Goats are important milk producers in several parts of the tropics and contribute significantly to human nutrition in many developing countries [3]. A goat is universally called as "Poor man's cow" due to its great contribution to the health and nutrition of handless and rural people [4]. Milk is considered as a staple food as it is a good source for protein, fat and major minerals essential for health [5].

In developing country like Nepal, dairy goat sector is less developed; hardly less than $5 \%$ of the milk is traded [6]. Most of the milk produced by the goats is either fed to kids by the does or generally home-consumed, given to the neighborhood or sold within the villages themselves. Dairy goats are supporting millions of malnourished human population in the developing world [7]. Goat milk has also been found to be useful for the patients of diabetes, peptic ulcers, allergy and various gastrointestinal disorders [4]. Thus, goats for dairying can prove an ideal preposition especially for 
developing world where majority of goat population is found with people having low economic status.

The fermented goat milk (yogurt) stimulates the mucosal immune system and improve the defense against intestinal and respiratory infections in an immunosuppressant model [8]. The large number of varieties of cheese can be made from pasteurized or unpasteurized goat milk $[9,10]$. Goat cheeses are highly nutritious and contain a high ratio of protein to calories [11] and have a liberal content of many minerals. Many varieties of cheese contain higher concentrations of some water soluble vitamins such as thiamin, riboflavin, and niacin, than does the milk from which cheese is made [12].

Cheese production in Nepal is coming up in a big way. Recently, Jamunapari and Saanen goat milk has been used for making soft and hard cheese in the country following the path of France [13]. Nepal Goat Cheese Company makes $70-80 \mathrm{~kg}$ of cheese per month, made from the milk provided by goats gifted to 30 families in the Chitlang village [14]. Although goat cheese is not a part of the traditional Nepalese diet, it has become popular with the more sophisticated inhabitants of Katmandu and with tourists frequenting large hotels in the area. Also, Goat Research Station, Bandipur, Tanahu, has been producing Cheese from Saanen milk [15].

Generally, all types of milk are composed of the same kind of constituents, but in different concentrations [16]. Compositions of goat milk vary with diet, breed, individuals, parity, season, feeding, management, environmental conditions, locality, stage of lactation, and health status of the udder [17] which also affects taste of milk. It differs from cow or human milk in having better digestibility, alkalinity, buffering capacity and therapeutics values in medicine and human nutrition [18]. Several studies have reported the distribution and occurrence of essential components in various animal milks [19]. The reported data show that the components of selected milk vary considerably and that their composition appears to be affected by animal source genetics as well as by physical and environmental factors [20]. This study will be very insightful to demonstrate variation in the physiochemical parameters of different goat milk which also affects the quality of milk byproducts.

\section{Methodology}

Fourty seven fresh milk samples, 11 from Boar goat, 11 from Saanen goat, 23 from cross breed of Khari and Boar and 2 from cross breed of Khari and Saanen were collected early in the morning. Milk samples were collected in $10 \mathrm{ml}$ clean sterile plastic bottles. Prior to milk collection, the udder were liberally washed with water and dried to avoid contamination. Following washing of the udder, the milk samples were collected directly in the bottles. Milk samples after collection were brought to the laboratory of Goat Research Station, Bandipur, Tanahu and kept for 2 hours at temperature $2-8^{\circ} \mathrm{C}$ until analysis. Before analyzing, the sample was stirred well for more than 5 minutes by vertical and circular slow movements and was filtered in order to be free from foreign fragments. Physiochemical analysis of milk samples was carried out in the laboratory using the ultrasonic milk analyzer (MilkoTester-Master Eco). The analysis was performed according to the manufacturer's instructions. Fat, protein, SNF (solid not fat), lactose, density, solids and freezing point were recorded as displayed on analyzer. To determine the density, 1,000 was added to the result on the display. Statistical data processing was performed using general linear model SPSS-16. Post Hoc Tukey test was done for the breed wise test of fat.

\section{Results}

\subsection{Fat}

Results illustrated that average fat content was $6.75 \pm 1.1 \%$ in pure Boar milk, $3.42 \pm 0.42 \%$ in pure Saanen, $7.78 \pm 2.34 \%$ in cross breed of Khari and Boar and $7.55 \pm 4.45 \%$ in cross breed of Khari and Saanen (Table 1). The amount of fat content in cross breed of Khari and Boar was higher than that in the milk of other species at highly significance $(p<0.005)$ level with Pure Saanen. There was non-significant $(p>0.05)$ difference between the amount of fat in Khari cross Saanen and Khari cross Boar milk. The amount of fat content in pure boar milk was significantly higher than that in the milk of pure Saanen $(\mathrm{p}<0.05)$ but lower than that in both cross breeds Khari cross Saanen and Khari cross Boar milk.

Table 1. Fat value of milk samples collected from different genetic groups of goats

\begin{tabular}{cccc}
\hline S.N. & Source of milk & Mean \pm SD & p-value \\
\hline 1. & Pure Boar & $6.75 \pm 1.11^{\mathbf{a}}$ & 0.002 \\
2. & Pure Saanen & $3.42 \pm 0.42^{\mathbf{b}}$ & \\
3. & Khari cross Boar & $7.78 \pm 2.34^{\mathbf{a}}$ & \\
4. & Khari cross Saanen & $7.55 \pm 4.45^{\mathbf{a}}$ & \\
\hline
\end{tabular}

Note: different superscript denotes significance. 


\subsection{Protein}

Protein content was found in the range $3.51 \pm 0.26 \%$ in Pure Boar milk, $3.24 \pm 0.41 \%$ in pure Saanen milk, $3.33 \pm$ $0.28 \%$ in Khari cross Boar milk and $2.95 \pm 0.07 \%$ in Khari cross Saanen milk (Table 2). There was non-significant difference between the amount of protein content and milk of different goat breed ( $>0.05)$. The amount of protein content in pure Boar, pure Saanen and cross breed of Khari and Boar milk was nearly similar. The cross breed of Khari and Saanen had the lowest amount of protein than in the milk of other species.

Table 2. Protein value of milk samples collected from different genetic groups of goats

\begin{tabular}{cccc}
\hline S.N. & Source of milk & Mean \pm SD & p-value \\
\hline 1. & Pure Boar & $3.51 \pm 0.26$ & 0.32 \\
2. & Pure Saanen & $3.24 \pm 0.41$ & \\
3. & Khari cross Boar & $3.33 \pm 0.28$ & \\
4. & Khari cross Saanen & $2.95 \pm 0.07$ & \\
\hline
\end{tabular}

\subsection{SNF}

SNF content was in range $9.73 \pm 0.71 \%$ in Pure Boar milk, $8.97 \pm 1.07 \%$ in pure Saanen milk, $9.55 \pm 1.58 \%$ in Khari cross Boar milk and $8.20 \pm 0.14 \%$ in Khari cross Saanen milk (Table 3). There was non-significant (p>0.05) difference between the amount of SNF content and milk of different goat breed. The amount of SNF content in pure Boar milk was higher than in the milk of other species.

Table 3. SNF value of milk samples collected from different genetic groups of goats

\begin{tabular}{cccc}
\hline S.N. & Source of milk & Mean \pm SD & p-value \\
\hline 1. & Pure Boar & $9.73 \pm 0.71$ & 0.60 \\
2. & Pure Saanen & $8.97 \pm 1.07$ & \\
3. & Khari cross Boar & $9.55 \pm 1.58$ & \\
4. & Khari cross Saanen & $8.20 \pm 0.14$ & \\
\hline
\end{tabular}

\subsection{Lactose}

Lactose content was found in the range $5.34 \pm 0.40 \%$ in pure Boar milk, $4.92 \pm 0.58 \%$ in pure Saanen milk, $5.22 \pm$ $0.86 \%$ in Khari cross Boar milk and $4.45 \pm 0.07 \%$ in Khari cross Sannen milk. There was non-significant ( $>0.05)$ difference between the amount of SNF content and milk of different goat breeds.

Table 4. Lactose value of milk samples collected from different genetic groups of goats

\begin{tabular}{cccc}
\hline S.N. & Source of milk & Mean \pm SD & p-value \\
\hline 1. & Pure Boar & $5.34 \pm 0.40$ & 0.56 \\
2. & Pure Saanen & $4.92 \pm 0.58$ & \\
3. & Khari cross Boar & $5.22 \pm 0.86$ & \\
4. & Khari cross Saanen & $4.45 \pm 0.07$ & \\
\hline
\end{tabular}

\subsection{Density}

Density content was found in the range $1.03 \pm 0.00 \mathrm{~g} / \mathrm{cm} 3$ in Pure Boar and Saanen milk and $1.02 \pm 0.00 \mathrm{~g} / \mathrm{cm} 3$ in Khari cross Boar milk and in Khari cross Saanen milk (Table 5). There was non-significant ( $>0.05$ ) difference in the density of milk of different goat breeds. Amount of density is higher in pure breed goat milk than cross breed.

Table 5. Density value of milk samples collected from different genetic groups of goats

\begin{tabular}{cccc}
\hline S.N. & Source of milk & Mean \pm SD & p-value \\
\hline 1. & Pure Boar & $1.03 \pm 0.00$ & 0.95 \\
2. & Pure Saanen & $1.03 \pm 0.00$ & $1.02 \pm 0.00$ \\
3. & Khari cross Boar & $1.02 \pm 0.00$ & \\
4. & Khari cross Saanen &
\end{tabular}




\subsection{Salt}

The amount of salt content in pure breed of Boar was higher than that in the milk of others (Table 6). There was non-significant $(\mathrm{p}>0.05)$ difference between the amount of SNF among different goat breeds. The amount of salt content in pure boar milk was higher than that in milk of their species milk. The cross breed of Khari and Saanen milk has the lowest amount of salt content.

Table 6. Salt value of milk samples collected from different genetic groups of goats

\begin{tabular}{cccc}
\hline S.N. & Source of milk & Mean \pm SD & p- value \\
\hline 1. & Pure Boar & $0.73 \pm 0.06$ & 0.41 \\
2. & Pure Saanen & $0.65 \pm 0.09$ & \\
3. & Khari cross Boar & $0.71 \pm 0.13$ & \\
4. & Khari cross Saanen & $0.60 \pm 0.00$ & \\
\hline
\end{tabular}

\subsection{Freezing Point}

Table 7. Freezing Point value of milk samples collected from different genetic groups of goats

\begin{tabular}{cccc}
\hline S.N. & Source of milk & Mean \pm SD & p- value \\
\hline 1. & Pure Boar & $0.65 \pm 0.05$ & 0.46 \\
2. & Pure Saanen & $0.57 \pm 0.78$ & \\
3. & Khari cross Boar & $0.64 \pm 0.12$ & \\
4. & Khari cross Saanen & $0.54 \pm 0.41$ & \\
\hline
\end{tabular}

\section{Discussion}

Lower protein, higher lactose and density in this study is in agreement with the research conducted by Hadohum (2017) [21], where protein, lactose and density $\left(\mathrm{g} / \mathrm{cm}^{3}\right)$ was $4.93 \%, 4.39 \%$ and 1.032 respectively. Also, protein range in this study, i.e., 2.95-3.51\% is similar and lactose range, i.e., 4.45-5.34\% is higher than the study carried out in Pakistan by Asif [22] where protein and lactose percentage is $3.15 \pm 0.32$ and $4.39 \pm 0.34$ respectively. These variances might be due to breed difference, health status of the udder, difference in feeds and lactation status. Similarly, in one of the work carried out in Saanen breed average protein percent, lactose percent, fat percent, density and freezing point were comparable to the result obtained from Saanen breed milk parameter of this study [23]. It was observed that the SNF, fat, lactose content found in goat milk was higher and protein content in accordance with the finding of Ahmed [24]. It was observed that the fat, protein and lactose content of Sannen were similar to that reported by Mioc [25]. The fat content was significantly affected by the factors breed, stage of lactation, season and parity in a similar research conducted by Zahraddeen [26]. Mioc found the lowest content of milk fat established in the mid stage of lactation whereas the highest fat content recorded at the end of the lactation [25]. Fat content was highest in the third parity followed by the second parity and least in the first parity. Wet season had higher fat content than the dry season [26]. So the variation in our finding, i.e., higher fat content in cross breed than pure breed Sannen and Boar may be due to different stages of lactation, breed, season and parity. The reason for the similar milk composition of some parameters as observed from the present study could be due to the fact that these goats were grazed under the same vegetative environment.

\section{Conclusion}

This study has shown that the parameters of milk vary depending on the breed of goats which ultimately affects the quality of different milk products. Further intensive studies should be carried out to investigate the nutritional value, physiological parameters and other properties of these types of milk, which are not covered in the present study. Peoples should be aware of the health benefits of consuming goat milk and the government should also encourage people to consume such milk and milk products.

\section{References}

[1] Alok Kumar Yadav, J. S. (2016). Composition, nutritional and therapeutic values of goat milk: A review. Asian Journal of Dairy and Food Research, 92-102.

[2] FAO. (1997). Production Yearbook 1996 (p. 2). Rome, Italy: Food and Agriculture Publications.

[3] Canagasaby Devendra, G. M. (1982). Goat and Sheep Production in the Tropics. In Goat and Sheep Production in the Tropics 
(pp. 218-219). Longman, London: Intermediate Tropical Agricultural Series, Longman Scientific and Technical Publishers.

[4] Arshad Iqbal, B. B. (2008). Goat-a potential dairy animal: present and future prospects. Pakistan journal of animal science, 45.

[5] Mohamed A Elbagerma, A. I. (2014). A Comparative Study on the Physicochemical Parameters and Trace Elements in Raw Milk Samples Collected from Misurata- Libya. sop transactions on analytical chemistry.

[6] Jean Paul Dubeuf, P. M.-F. (2004). Situation, changes and future of goat industry around the world. Small Ruminant Research, 165-173.

[7] Seilsuth, S., Seo, J. H., Kong, H. S., \& Jeon, G. J. (2016). Microsatellite analysis of the genetic diversity and population structure in dairy goats in Thailand. Asian-Australasian Journal of Animal Sciences, 29(3), 327.

[8] Salva, S., Nuñez, M., Villena, J., Ramón, A., Font, G., \& Alvarez, S. (2011). Development of a fermented goats’ milk containing Lactobacillus rhamnosus: in vivo study of health benefits. Journal of the Science of Food and Agriculture, 91(13), 2355-2362.

[9] Loewenstein, M., Speck, S. J., Barnhart, H. M., \& Frank, J. F. (1980). Research on goat milk products: a review. Journal of Dairy Science, 63(10), 1631-1648.

[10] Bottazzi, V. (1975). Peculiarities of principal Italian cheeses. American Dairy Review, 37(10), 25.

[11] Dozet, N. (1973). Composition and nutritional value of goat’s milk products. In Dairy Sci. Abstr (Vol. 35, p. 3147).

[12] Adams, C. F. (1975). Nutritive value of American foods in common units (No. 456). Agricultural Research Service, US Department of Agriculture.

[13] Bhattarai, R. R. (2012). Importance of goat milk. Journal of Food Science and Technology Nepal, 7, 107-111.

[14] Taylor, S. (2006). Goat cheese on top of the world. Chèvre, (276), 52-54.

[15] Shrestha, A., Raju Kadel, B. B. K., Dahal, M., Ghimire, S. H., Malla, S., \& Shrestha, P. B. (2019). Preparation of cheese from the saanen's milk at goat research station, bandipur, tanahu. In 11th National Workshop on Livestock and Fisheries Research in Nepal (p. 224).

[16] Elhefian, E. A. (2017). Physicochemical Characteristics of Various Milk Samples. Nova Journal of Medical and Biological Sciences.

[17] Park, Y. (2007). Impact of goat milk and milk products on human nutrition. Perspectives in Agriculture, Veterinary Science, Nutrition and Natural Resources, 81.

[18] Getaneh, G., Mebrat, A., Wubie, A., \& Kendie, H. (2016). Review on goat milk composition and its nutritive value. J. Nutrs. Health Sci, 3, 401-409.

[19] AM Kholif, S. A.-N.-A.-A. (1994). Effect of spraying diazinon to control the external parasites on the productive performance of dairy animals-1. Yield and composition of buffaloes' and friesian cows' milks. Egyptian Journal of Dairy Science, 145-145.

[20] Enb, A., Abou Donia, M. A., Abd-Rabou, N. S., Abou-Arab, A. A. K., \& El-Senaity, M. H. (2009). Chemical composition of raw milk and heavy metals behavior during processing of milk products. Global Veterinaria, 3(3), 268-275.

[21] Hadohum M. M., Hend M. A., Somia S. A., Marowa A. A., Tark M. H., Esam A. E., \& Fathi M. A. (2017, January). Physiochemical Characteristics of Various Milk Samples. Nova Journal of Medical and Biological Sciences, 6(2), 1-3. doi:10.20286/nova-jmbs-060201.

[22] Asif, M., \& Sumaira, U. (2010). A Comparative study on the Physicochemical Parameters of Milk Samples Collected from Buffalo, cow, Goat and Sheep of Gujrat, Pakistan. Pakistan Journal of Nutrition, 1192-1197.

[23] Zamfirescu, S., Dobrin, N., Cismileanu, A., Voicu, I., Jitariu, D., \& Sava, A. (2017). Variations of the biochemical profile of goat milk under the influence of protetics and energy level of feed ratio. The Romanian Society for Cell Biology, 21(2), 59-67.

[24] Ahmed, I. (2016). Comparative Study of Cottage Cheese Prepared from Various Sources of Milk. In proceedings of the Pakistan Academy of Sciences (53), 269-282.

[25] Mioč, B., Prpić, Z., Vnučec, I., Barać, Z., Sušić, V., Samaržija, D., \& Pavić, V. (2008). Factors affecting goat milk yield and composition. Mljekarstvo/Dairy, 58(4).

[26] Zahraddeen, D., Butswat, I. S. R., \& Mbap, S. T. (2007). Evaluation of some factors affecting milk composition of indigenous goats in Nigeria. Livestock Research for Rural Development, 19(11), 166. 